\title{
PENILAIAN SAHAM PT PEMBANGUNAN PERUMAHAN PROPERTI DALAM RANGKA INITIAL PUBLIC OFFERING
}

\author{
Rifki Khoirudin \\ Departemen Ekonomi Pembangunan Fakultas Ekonomi dan Bisnis \\ Universitas Ahmad Dahlan \\ Jl. Kapas No.9 Semaki Umbulharjo, Yogyakarta, 55166, Indonesia
}

\begin{abstract}
Keywords: Company Valuation, Initial Public

Offerings, Discounted Chash Flow, Relative Valuation.

JEL Classification: G11, G12, L74

This research aimed to estimate fair value per share of PT Pembangunan Perumahan Properti Tbk. as a comparison value to the offered price, set at the time of Initial Public Offering (IPO). This research also aimed to determine whether the price offered at the time of IPO was undervalued or overvalued. Information used in this research was in the form of secondary data of PT Pembangunan Perumahan Properti, financial report of comparable companies, and stock prices of comparable companies. The analyzing tools used to determine the fair value per share were discounted cash flow method and relative valuation method. The discounted cash flow method was performed through: projection of the financial statements i.e. the balance sheet and income statement, projection of Free Cash Flow to Equity (FCFE), determination of the discount rate, determination of terminal value, and determining the estimated value of the equity. The relative valuation method was established by searching, choosing and determining the appropriate multiple of comparable companies in similar bussines. Multiples used were: Price Earnings Ratio (PER), Price to Book Value (PBV), and Price to Sales Ratio $(P / S)$.
\end{abstract}

Kata Kunci:

Penilaian

Perusahaan, Initial

Public Offering,

Discounted Chash

Flow, Relative

Valuation.

\begin{abstract}
Abstrak
Penelitian ini bertujuan untuk mengestimasi nilai wajar per lembar saham PT Pembangunan Perumahan Properti sebagai nilai pembanding bagi harga penawaran yang telah ditetapkan pada saat Initial Public Offering (IPO). Penelitian ini juga dimaksudkan untuk mengetahui apakah harga penawaran yang ditetapkan pada saat IPO berada dalam kondisi undervalued atau overvalued. Informasi yang digunakan dalam penelitian ini berasal dari data sekunder berupa laporan keuangan PT Pembangunan Perumahan Properti, laporan keuangan perusahaan pembanding, dan data harga saham perusahaan pembanding. Metoda analisis yang digunakan untuk menentukan nilai wajar per lembar saham adalah Discounted Cash Flow dan Relative Valuation. Analisis metoda Discounted Cash Flow dilakukan dengan cara: proyeksi laporan keuangan yaitu neraca dan laporan laba rugi, proyeksi Free Cash Flow to Equity (FCFE), penentuan tingkat diskonto, penentuan Terminal Value, dan estimasi nilai wajar ekuitas. Analisis Relative Valuation dimulai dengan mencari perusahaan pembanding dalam bidang usaha yang sama, memilih dan menetapkan multiple yang sesuai dari perusahaan pembanding. Multiple yang digunakan adalah: Price Earnings Ratio (PER), Price to Book Value (PBV), dan Price to Sales Ratio (P/S).
\end{abstract}




\section{Jurnal Keuangan dan Perbankan | KEUANGAN}

Vol. 21, No.1, Januari 2017: 37- 46

Pada umumnya setiap perusahaan mempunyai keinginan untuk memperluas usahanya, hal ini dilakukan dengan mengadakan ekspansi. Untuk melakukan ekspansi ini perusahaan memerlukan tambahan modal cukup besar. Dalam rangka memenuhi kebutuhan dana yang cukup besar tersebut, sering kali dana yang diambil dari dalam perusahaan tidak cukup. Untuk itu diperlukan usaha mencari sumber dana dari luar perusahaan, yaitu di pasar modal, dengan cara melakukan emisi saham.

Pengertian pasar modal menurut UU Pasar Modal No. 8 Tahun 1995 adalah kegiatan yang bersangkutan dengan penawaran umum dan perdagangan efek, perusahaan publik yang berkaitan dengan efek yang diterbitkannya, serta lembaga profesi yang berkaitan dengan efek. Ketika suatu perusahaan melakukan penawaran sahamnya untuk pertama kali atau Initial Public Offering (IPO), transaksi tersebut terjadi di pasar perdana. Harga yang terbentuk di pasar perdana ini merupakan kesepakatan antara pihak emiten dengan pihak penjamin emisi (underwriter). Kemudian saham-saham tersebut dapat diperdagangkan di pasar sekunder. Harga yang terbentuk di pasar ini sesuai dengan permintaan dan penawaran (Emilia et al., 2008)

IPO atau penawaran umum saham perdana merupakan salah satu usaha yang lebih disukai dalam menghimpun dana untuk membiayai keberlangsungan perusahaan (Wardani \& Fitriati, 2010). Penilaian suatu perusahaan pada saat IPO penting untuk dilakukan karena merupakan kesempatan pertama bagi masyarakat untuk menilai sekumpulan aset dari suatu perusahaan. Penilaian untuk tujuan IPO juga relevan dari sisi efisiensi ekonomi, karena IPO adalah kesempatan pertama bagi manajer dari perusahaan lain untuk mengamati sinyal harga dari pasar modal.

PT Pembangunan Perumahan Properti merupakan anak perusahaan dari PT Pembangunan Perumahan Tbk. (PT PP Tbk.). PT Pembangunan Per- umahan Properti bergerak di bidang kontraktor proyek-proyek pembangunan properti. Terkait rencana penggunaan dana hasil IPO, rencananya akan digunakan untuk proyek pembangunan properti di Australia yang menurut perusahaan memberikan return yang tinggi dan pemasarannya tidak membutuhkan waktu yang terlalu lama.

Valuation model dimaksudkan untuk melihat benchmark secara kuantitatif dalam evaluasi harga pada saat ini, serta harga yang diharapkan di masa yang akan datang berdasarkan asumsi dan faktor fundamental. Selain itu untuk memberikan pemikiran guna memahami hubungan antara faktorfaktor fundamental dan dampak perubahannva terhadap penilaian saham. Secara umum metode penilaian saham dikelompokkan menjadi 2, yaitu analisis fundamental dan analisis teknikal (Singgih, 2012).

Noor \& Satyawan (2014) melakukan penelitian tentang analisis penilaian harga saham wajar pada PT Multi Bintang Indonesia Tbk. Penelitian ini menggunakan pendekatan pendapatan dengan metode Discounted Discount Model (DDM). Penelitian ini menggunakan laporan keuangan perusahaan pada tahun 2010-2013 dan laporan keuangan perusahaan yang sebanding dalam bidang usaha. Hasil Penelitian tersebut menunjukkan harga saham PT Multi Bintang Indonesia Tbk dibandingkan dengan estimasi nilai intrinsiknya pada tahun 2011 mengalami undervalued, sedangkan pada tahun 2012 dan 2013 mengalami overvalued.

Muttaqim (2013) melakukan penelitian tentang analisis valuasi saham PT Adhi Karya (Persero) Tbk. Penelitian ini menggunakan metode Discounted Cash Flow (DCF) yaitu dengan Free Cash Flow to Firm (FCFF). Hasil penelitian menunjukkan bahwa harga wajar per lembar saham PT Adhi Karya (Persero) Tbk. sebesar Rp714,00 per lembar, sedangkan harga pasar saham dari transaksi yang terjadi pada tanggal 22 Desember 2011 sebesar Rp764,61 per lembar. 


\section{Penilaian Saham PT Pembangunan Perumahan Properti dalam Rangka Initial Public Offering \\ Rifki Khoirudin}

Aisyah (2009) melakukan penelitian tentang Pengaruh Variabel-Variabel Keuangan pada Initial Return Saham di Pasar Perdana. Metode analisis data yang digunakan dalam penelitian ini adalah analisis regresi linier berganda, untuk menguji kekuatan hubungan antara initial return dengan rate of Return on Total Assets (ROA), Total Assets Turn Over (TATO), Financial Leverage (FL), Earning Per Share (EPS), Current Ratio (CR), dan Besaran Perusahaan (BP). Hasil penelitian ini menunjukkan variabel-variabel keuangan secara bersama-sama berpengaruh signifikan terhadap initial return saham di pasar perdana pada Bursa Efek Jakarta.

Haryanto \& Kartawinata (2014) melakukan penelitian tentang Kinerja Saham Perusahaan yang Melakukan Initial Public Offering (IPO) di Bursa Efek Indonesia Periode 2014. Jenis penelitian ini adalah penelitian deskriptif dengan menggunakan data sekunder. Populasi dalam penelitian ini adalah semua saham perusahaan yang terdaftar di Bursa Efek Indonesia selama periode penelitian yang terdiri dari 23 perusahaan. Kinerja saham diukur menggunakan initial return untuk penawaran saham perdana dan abnormal return dengan model market-adjusted abnormal return untuk jangka menengah (3 bulan) dan jangka panjang (12 bulan). Hasil penelitian ini adalah perusahaan yang melakukan IPO pada tahun 2014 dengan 20 perusahaan mengalami underpricing, 2 perusahaan mengalami overpricing, dan 1 perusahaan mengalami truepricing. Dari 23 sampel, hasil analisis membuktikan bahwa rata-rata initial return adalah positif sebesar $23,32 \%$ mengalami underpricing pada saat awal perusahaan melakukan IPO. Hasil penelitian yang menunjukkan initial return yang underpricing juga sejalan dengan penelitian Younesi et al. (2012) bahwa terjadi underpricing saham-saham perusahaan yang melakukan IPO tahun 2007-2010 di pasar modal Malaysia.

IPO merupakan suatu kegiatan perusahaan penawaran saham pertama kali kepada masyarakat umum berdasarkan tata cara yang diatur oleh undang-undang dan peraturan pelaksanaannya. Kegiatan penawaran umum perdana dilakukan sebagai salah satu alternatif untuk memperoleh sumber dana (Abid \& Muharam, 2013).

Berdasarkan uraian tersebut, maka yang menjadi tujuan dalam penelitian ini adalah untuk mengestimasi nilai wajar per lembar saham PT Pembangunan Perumahan Properti sebagai nilai pembanding bagi harga penawaran yang telah ditetapkan pada saat IPO. Penelitian ini juga dimaksudkan untuk mengetahui apakah harga penawaran yang ditetapkan pada saat IPO berada dalam kondisi undervalued atau overvalued.

\section{METODE}

Penelitian ini menggunakan 2 pendekatan untuk menentukan nilai wajar ekuitas. Pendekatan pertama adalah pendekatan pendapatan/Discounted Cash Flow (DCF) dengan Free Cash Flow To Equity Model (FCFE). Pendekatan kedua yang digunakan adalah pendekatan pasar (relative valuation) dengan menggunakan Price Earning Ratio (PER), Price to Book Value (PBV), dan Price to Sales Ratio (P/S).

Pendekatan ini mengestimasi nilai intrinsik dari suatu aset dengan cara mendiskontokan nilai arus kas masa depan. Menurut Damodaran (2012), metode DCF ini digunakan untuk menilai ekuitas dalam bisnis, menilai perusahaan secara keseluruhan, dan untuk menilai bagian kecil dari perusahaan. Ada beberapa metode diskonto yang sering kali digunakan, antara lain adalah Free Cash Flow to Firm (FCFF) dan FCFE. Valuasi dengan menggunakan FCFF, mengukur nilai perusahaan, termasuk pemilik klaim lain dalam perusahaan seperti bondholder, namun tidak spesifik seperti FCFE dimana valuasi dilakukan hanya untuk mengukur nilai perusahaan dari sisi ekuitas saja, sehingga dapat menilai apakah ekuitas tersebut dinilai oleh pasar overvalued atau undervalued. Penelitian ini hanya akan membahas mengenai metode FCFE. 


\section{Teknik Analisis}

\section{Proyeksi laporan keuangan}

Untuk melakukan estimasi nilai wajar saham perusahaan dengan menggunakan metoda DCF dengan FCFE, terlebih dahulu harus ditentukan periode proyeksinya. Periode proyeksi dapat dikembangkan dalam rentang waktu beberapa tahun, tetapi sebagian besar perusahaan menggunakan rentang waktu 5-10 tahun (Brigham \& Ehrhardt, 2009). Sedangkan jika berdasarkan Keputusan Kepala BAPEPAM-LK No. Kep-340-BL/2012, paling kurang rentang waktunya adalah 5 tahun.

\section{Mengestimasi tingkat pertumbuhan}

Untuk menentukan tingkat pertumbuhan $\mathrm{g}$, digunakan rumus:

$\mathrm{g}=\mathrm{ROE} \times$ Retention Rate

Keterangan:

Retention rate $=1$ - dividend payout ratio atau persentase laba ditahan

ROE $=$ laba bersih/total modal

Retention rate adalah rasio antara laba ditahan dengan laba bersih yang telah disesuaikan. ROE adalah rasio laba bersih yang telah disesuaikan dengan nilai ekuitas dalam neraca.

\section{Cost of equity}

Risiko sering dihubungkan dengan penyimpangan/deviasi dari outcome yang diterima dengan yang diekspektasi. Risiko sistematis (systematic risk) adalah variasi pengembangan saham/ portofolio berhubungan dengan perubahan pengembangan dalam pasar secara keseluruhan. Risiko yang tidak dapat didiversifikasikan disebut sebagai risiko pasar atau risiko umum atau risiko sistematik. Risiko ini terjadi karena kejadian-kejadian di luar kegiatan perusahaan seperti inflasi, resesi. dan sebagainya (Solechan, 2009).
Cost of equity merupakan tingkat pengembalian yang diharapkan oleh para investor terhadap dana yang mereka investasikan di perusahaan tersebut. Salah satu pendekatan yang banyak dipergunakan untuk melakukan estimasi cost of equity adalah dengan menggunakan CAPM (Capital Asset Pricing Model) (Damodaran, 2012). Secara umum persamaan CAPM adalah sebagai berikut:

$\mathrm{K}_{\mathrm{e}}=\mathrm{R}_{\mathrm{f}}+\beta\left(\mathrm{R}_{\mathrm{m}}-\mathrm{R}_{\mathrm{f}}\right)$

Keterangan:

$\mathrm{R}_{\mathrm{f}}=$ nilai risk-free rate,

$\beta=$ systematic risk dari ekuitas perusahaan di mana nilainya didapat dari hasil regresi return dari saham perusahaan tersebut terhadap market return

$\left(\mathrm{R}_{\mathrm{m}}-\mathrm{R}_{\mathrm{f}}\right)=$ merupakan nilai expected equity risk premium

Besarnya imbal hasil yang diharapkan dari suatu portofolio (expected return portofolio) dipengaruhi oleh besarnya beta (â) yang menggambarkan besarnya risiko sistematis dari suatu saham dan besarnya alokasi dana yang diinvestasikan untuk saham yang bersangkutan (Umanto, 2008). Untuk menentukan nilai beta perusahaan, privat dilakukan dengan menggunakan metoda bottom up beta atau teknik Hamada. Hamada menggunakan model penyesuaian beta bila terdapat perubahan leverage, kemudian dari leverage beta terebut akan diperoleh beta unleverage, dengan pendekatan sebagai berikut:

$\beta_{\mathrm{L}}=\beta_{\mathrm{U}}[1+(1-\mathrm{T})(\mathrm{D} / \mathrm{E})]$

$\beta_{\mathrm{U}}=\beta_{\mathrm{L}} /[1+(1-\mathrm{T})(\mathrm{D} / \mathrm{E})]$

Keterangan:

$\beta_{\mathrm{L}}=$ beta perusahaan yang memiliki leverage

$\beta_{\mathrm{U}}=$ beta perusahaan yang tidak memiliki leverage

$\mathrm{T}=$ tingkat pajak perusahaan

$\mathrm{D} / \mathrm{E}=$ rasio utang per ekuitas 


\section{Penilaian Saham PT Pembangunan Perumahan Properti dalam Rangka Initial Public Offering \\ Rifki Khoirudin}

\section{Free Cash Flow to Equity (FCFE)}

Salah satu informasi penting dari laporan keuangan yang sering digunakan investor sebagai determinan utama pengambilan keputusan investasi adalah kinerja perusahaan. Kinerja perusahaan ini mencerminkan kekuatan perusahaan yang angka-angkanya diambil dari laporan keuangan (Sunardi, 2010). FCFE diambil dari laporan kuangan dan dihitung dengan mengurangi laba bersih dengan kebutuhan investasi dan menjumlahkan semua transaksi non kas seperti deperesiasi. Kemudian dikurangi modal kerja non kas dan ditambahkan dengan net kas masuk dari penerbitan utang (Damodaran, 2012).

Menurut perhitungan, net cash flow to equity (NCFE) menggunakan rumus berikut:

$\mathrm{NCFE}=\mathrm{NIAT}+\mathrm{NCC}-\mathrm{CAPEX}-\mathrm{CNWC}+$ NCLTD

Keterangan:

NIAT = Net Income after tax

NCC $=$ Non Cash Charge

CAPEX = Capital Expenditure

CNWC = Change in Net Working Capital

NCLTD $=$ Net Change in Long Term Debt

\section{Terminal value}

Perhitungan terminal value menurut Damodaran (2012) didasarkan pada kenyataan bahwa estimasi aliran kas tidak dapat dilakukan setiap tahun selamanya, sehingga biasanya dilakukan penutupan dalam penilaian DCF dengan menghentikan estimasi cash flow pada suatu tahun (tahun terminal/ tahun akhir estimasi) untuk kemudian dilakukan penghitungan nilai terminal yang merefleksikan nilai perusahaan pada saat itu (Damodaran, 2012). Sementara menurut rumus umum yang digunakan dalam terminal value adalah sebagai berikut:
Terminal Value $=\frac{F C F E_{n+1}}{K_{e, S t}-g_{n}}$

Keterangan:

$\mathrm{FCFE}_{\mathrm{n}+1}=$ arus kas bersih pada tahun $\mathrm{n}$

$\mathrm{K}_{\mathrm{e}, \mathrm{st}} \quad=$ cost of equity periode stable growth

$\mathrm{g}_{\mathrm{n}} \quad=$ tingkat pertumbuhan stabil

\section{Penentuan nilai ekuitas}

Nilai dari ekuitas adalah penjumlahan dari nilai kini dari arus kas bersih perusahaan pada pertumbuhan tinggi ditambah dengan nilai kini terminal value pada pertumbuhan stabil. Rumus umum dalam menentukan nilai ekuitas dapat dirumuskan sebagai berikut:

Nilai ekuitas $=\sum_{t=1}^{t=n} \frac{F C F E}{\left[(1-k)_{e, h g}\right]^{t}}+\frac{\text { Terminal Value }}{\left[(1-k)_{e, h g}\right]^{t}}$

Keterangan:

$\mathrm{FCFE}_{\mathrm{t}}=$ free cash flow to equity

$\mathrm{n} \quad=$ umur aset

$\mathrm{K}_{\mathrm{e}} \quad=$ cost of equity

\section{Relative valuation}

Relative valuation adalah valuasi perusahaan yang paling sering digunakan. Kelebihan dari metode valuasi ini adalah mudah digunakan, tidak menghabiskan waktu, dan tidak menuntut banyak asumsi dibandingkan metode valuasi discounted cash flow maupun contingent claim. Relative valuation sangat mudah digunakan, sehingga membuatnya menjadi metode yang kuat dimana data kunci dalam bentuk rasio keuangan yang berbeda-beda telah tersedia (Mahendra et al., 2012). Penggunaan informasi rasio keuangan yang disediakan sebuah perusahaan biasanya analis atau investor akan menghitung rasio-rasio keuangannya untuk dasar pertimbangan dalam keputusan investasi. 


\section{Jurnal Keuangan dan Perbankan | KEUANGAN}

Vol. 21, No.1, Januari 2017: 37- 46

\section{Price/ earning ratio}

Earnings ratio adalah rasio antara harga saham per lembar dengan pendapatan per lembar. Multiple ini paling banyak digunakan. Nilai ekuitas diperkirakan dengan melihat kemampuan perusahaan dalam menghasilkan laba bersih per saham (Damodaran, 2012).

$\mathrm{PER}=\frac{\text { Market } \text { Price per Share }}{\text { Earnings per Share }}$

\section{Price/sales ratio}

Sales ratio adalah rasio antara nilai pasar ekuitas dibandingkan dengan pendapatannya (revenues). Nilai ekuitas dipekirakan dengan melihat kemampuan perusahaan dalam menghasilkan penjualan/penerimaan (Damodaran, 2012).

$P / S$ Sales ratio $=\frac{\text { Nilai Pasar Ekuitas }(\text { Market Value of Equity) }}{\text { Pendapatan (Revenue) }}$

\section{Price / book value}

Book value adalah rasio antara harga pasar saham per lembar dengan nilai buku ekuitas per lembar (Damodaran, 2012).

$\mathrm{PBV}=\frac{\text { Market Value per Share }}{\text { Earnings per Share }}$

\section{Discount for lack of marketability}

Discount adalah potongan yag diberikan kepada suatu indikasi nilai dari business interest atau saham yang berhasil diperkirakan. Pemberian diskon yang terkait dengan unsur kendali disebut minority interest discount. Pemberian diskon juga terkait dengan tingkat kesulitan saham tersebut untuk dikonversi secara cepat menjadi uang tunai, diskon jenis ini disebut discount for lack of marketability.

Diskon likuiditas pasar (discount for lack of marketabilities) adalah suatu jumlah atau persentase tertentu yang merupakan pengurang dari nilai suatu ekuitas sebagai cerminan dari kurangnya likuiditas objek penilaian (Keputusan Ketua Badan Pengawas Pasar Modal dan Lembaga Keuangan Nomor: KEP196/BL/2012)

\section{Penetapan rekonsiliasi nilai}

Rekonsiliasi nilai dilakukan dengan mempertimbangkan tujuan dilakukannya penilaian dalam penelitian ini, mengkaji kembali apakah metoda penilaian yang digunakan sudah sesuai dan apakah indikasi nilai yang diperoleh itu telah rasional. Hasil rekonsiliasi nilai dilakukan dengan membuang indikasi nilai yang tidak sesuai atau memberikannya bobot yang rendah terhadap nilai yang dianggap melenceng.

\section{HASIL}

\section{Mengestimasi Tingkat Pertumbuhan}

Retention ratio adalah rasio antara laba ditahan dengan laba bersih yang telah disesuaikan. ROE adalah rasio laba bersih yang telah disesuaikan dengan nilai ekuitas dalam neraca. Perhitungannya adalah sebagai berikut:

ROE = Laba Bersih / Total Ekuitas

Rp106.120.564.723,00 / Rp1.031.328.324.833,00 x $100=10,29 \%$

Dengan rumus tersebut, maka perhitungannya adalah sebagai berikut: $g=10,29 \% \times 1=10,29 \%$

\section{Cost of Equity}

Mengestimasi faktor diskonto atau cost of equity yang merupakan tingkat pengembalian yang disyaratkan oleh investor. Perhitungan cost of equity menggunakan metoda capital asset pricing model (CAPM). Berdasarkan metode CAPM, tingkat pengembalian yang disyaratkan investor diperoleh 


\section{Penilaian Saham PT Pembangunan Perumahan Properti dalam Rangka Initial Public Offering \\ Rifki Khoirudin}

dari tingkat suku bunga bebas risiko ditambah dengan perkalian antara beta perusahaan dengan premi risiko. Adapun hasil perhitungan cost of equity $\left(\mathrm{k}_{\mathrm{e}}\right)$ PT PP Properti ditunjukkan pada Tabel 1.

Tabel 1. Perhitungan Cost of Equity $\left(\mathrm{k}_{\mathrm{e}}\right)$ PT PP Properti

\begin{tabular}{lcl}
\hline \multicolumn{1}{c}{ Uraian } & & Keterangan \\
\hline Rf & $7,96 \%$ & Obligasi Negara RI \\
& & Seri FR0071 \\
Rm-Rf & $9,05 \%$ & Aswath Damodaran \\
Beta & 1,2 & Leverage Beta \\
\hline Cost of Equity & $18,84 \%$ & Ke $=$ Rf $+\beta($ Rm-Rf $)$ \\
\hline
\end{tabular}

Dalam penelitian ini perusahaan yang digunakan sebagai pembanding adalah PT. Adhi Karya (Persero) Tbk. dan PT. Wijaya Karya (Persero) Tbk. Perusahaan tersebut dipilih karena sama-sama dimiliki oleh pemerintah sebagai pemegang saham mayoritas sehingga risikonya pun berbeda antara yang swasta murni dengan perusahaan negara karena perusahaan BUMN akan lebih mudah untuk mendapatkan proyek pembangunan dari pemerintah dan bergerak dibidang industri yang sama yaitu properti.

\section{Free Cash Flow to Equity (FCFE)}

Hasil perhitungan FCFE PT PP Properti ditunjukkan pada Tabel 2.

\section{Terminal Value}

Dengan asumsi bahwa perusahaan akan terus beroperasi (going concern), maka proyeksi terhadap laporan keuangan dibatasi oleh 2 kondisi. Kondisi pertama merupakan kondisi di mana perusahaan akan tumbuh tinggi, setelah itu memasuki kondisi kedua dengan pertumbuhan stabil. Pertumbuhan yang stabil ini menjadi acuan penetapan terminal value dari nilai ekuitas. Adapun hasil perhitungan terminal value PT PP Properti ditunjukkan pada Tabel 3.

Tabel 3. Perhitungan Terminal Value PT PP Properti (Dalam Milyar Rupiah)

\begin{tabular}{ccccc}
\hline \multicolumn{5}{c}{ Uraian } \\
\hline $\begin{array}{c}\text { Constant } \\
\text { Growth }\end{array}$ & FCFE 5 & $\begin{array}{c}\text { FCFE } \\
\mathrm{n}+1\end{array}$ & Ke & $\begin{array}{c}\text { Terminal } \\
\text { Value }\end{array}$ \\
\hline $9 \%$ & 297 & 324 & $18,84 \%$ & 3,295 \\
\hline
\end{tabular}

\section{Estimasi Nilai Wajar Ekuitas}

Dalam konsep pendekatan pendapatan/discounted cash flow dengan free cash flow to equity model, estimasi nilai wajar ekuitas merupakan penjumlahan dari nilai kini equity dan terminal value. Dari perhitungan tersebut diperoleh estimasi nilai wajar ekuitas PT PP Properti sebesar Rp 176. Berikut perhitungan nilai ekuitas per lembar saham PT PP Properti. Adapun hasil perhitungan nilai ekuitas PT PP Properti ditunjukkan pada Tabel 4.

Tabel 2. Perhitungan FCFE PT PP Properti (Dalam Milyar Rupiah)

\begin{tabular}{lrrrrrr}
\hline \multicolumn{1}{c}{ Uraian } & $\mathbf{g = 1 0 , 2 9 \%}$ & Aktual & \multicolumn{5}{c}{ Tahun Proyeksi } \\
\hline \multicolumn{1}{c}{ Per 31 Desember } & $\mathbf{2 0 1 4}$ & $\mathbf{2 0 1 5}$ & $\mathbf{2 0 1 6}$ & $\mathbf{2 0 1 7}$ & $\mathbf{2 0 1 8}$ & $\mathbf{2 0 1 9}$ \\
\hline Net Income (NIAT) & 106 & 117 & 129 & 142 & 157 & 173 \\
Depresiasi dan amortisasi (NCC) & 20 & 23 & 25 & 28 & 30 & 34 \\
Perubahan working capital (CNWC) & 60 & 66 & 73 & 80 & 89 & 98 \\
Perubahan capital expenditure (CAPEX) & 102 & 113 & 124 & 137 & 151 & 167 \\
Perubahan hutang jangka panjang (NCLTD) & 218 & 240 & 265 & 292 & 322 & 355 \\
FCFE & 182 & 201 & 221 & 244 & 269 & 297 \\
\hline
\end{tabular}

Keterangan: FCFE $=$ NIAT + NCC - CAPEX - CNWC + NCLTD 
Tabel 4. Perhitungan Nilai Ekuitas PT PP Properti

\begin{tabular}{lccr}
\hline Uraian & Jumlah & \multicolumn{1}{c}{ Diskonto } & $\begin{array}{c}\text { Nilai } \\
\text { Sekarang }\end{array}$ \\
\hline FCFE 1 & 201 & 0,8415 & 169 \\
FCFE 2 & 221 & 0,7081 & 157 \\
FCFE 3 & 244 & 0,5958 & 145 \\
FCFE 4 & 269 & 0,5014 & 135 \\
FCFE 5 & 297 & 0,4219 & 125 \\
Jumlah (A) (Milyar Rupiah) & 732 \\
Terminal Value (B) (Milyar Rupiah) & 3.295 \\
Jumlah (A+B) (Milyar Rupiah) & 4.028 \\
Jumlah saham yang beredar pada & \\
saat IPO & 9.132 .060 .000 \\
Indikasi nilai per lembar saham & 441 \\
Discount for lack of marketability 30\% & 132 \\
Discount for lack of control 30\% & 132 \\
Indikasi nilai & ekuitas setelah di & 176 \\
diskon & & \\
\hline
\end{tabular}

\section{Relative Valuation}

\section{Price Earning Ratio (PER)}

Price Earning Ratio adalah rasio dengan membandingkan antara harga per lembar saham dengan pendapatan per lembar saham. Tabel 5 menunjukkan perhitungan Price Earning Ratio (PER) dari perusahaan pembanding.

Tabel 5. Perhitungan Price Earning Ratio (PER)

\begin{tabular}{lc}
\hline \multicolumn{1}{c}{ Nama Perusahaan } & PER \\
\hline PT. Adhi Karya (Persero) Tbk. & 46,54 \\
PT. Wijaya Karya (Persero) Tbk. & 84,55 \\
\hline Rata-rata & 65,55 \\
\hline
\end{tabular}

\section{Price to Book Value (PBV)}

Price to book value (PBV) adalah rasio dengan membandingkan antara harga pasar per lembar saham dengan nilai buku ekuitas per lembar saham. Tabel 6 menunjukkan perhitungan PBV dari perusahaan pembanding.

Tabel 6. Perhitungan Price to Book Value (PBV)

\begin{tabular}{lr}
\hline \multicolumn{1}{c}{ Nama Perusahaan } & PBV \\
\hline PT. Adhi Karya (Persero) Tbk. & 4,10 \\
PT. Wijaya Karya (Persero) Tbk. & 5,90 \\
\hline Rata-rata & 5,00 \\
\hline
\end{tabular}

\section{Price to Sales Ratio (P/S)}

Price to Sales Ratio (P/S) adalah rasio multiple dengan membandingkan antara harga pasar dari ekuitas dan pendapatan yang diperoleh. Tabel 7 menunjukkan perhitungan $\mathrm{P} / \mathrm{S}$ dari perusahaan yang dijadikan sebagai pembanding dalam penelitian ini.

Tabel 7. Perhitungan Price to Sales Ratio (P/S)

\begin{tabular}{lr}
\hline \multicolumn{1}{c}{ Nama Perusahaan } & P/S \\
\hline PT. Adhi Karya (Persero) Tbk. & 0,72 \\
PT. Wijaya Karya (Persero) Tbk. & 1,39 \\
\hline Rata-rata & 1,05 \\
\hline
\end{tabular}

Nilai ekuitas dari ketiga multiple di atas, selanjutnya dikalikan dengan discount for lack of marketability (DLOM) sebesar 30\% dan discount for lack of control, kemudian hasilnya dijadikan ratarata untuk mendapat estimasi nilai per lembar saham. Tabel 8 menunjukkan nilai per lembar saham dengan pendekatan relative valuation.

Tabel 8. Nilai Per Lembar Saham dengan Pendekatan Relative Valuation

\begin{tabular}{lrcccr}
\hline Uraian & Pengali & EPS & BVS & RPS & Jumlah \\
\hline PER & 11,62 & 65,55 & & & 762 \\
PBV & 112,93 & & 5 & & 565 \\
P/S & 61 & & & 1,05 & 64 \\
Rata-rata & & & & & 464 \\
DLOC & & & $30 \%$ & 139 \\
DLOM & & $30 \%$ & 139 \\
\hline Indikasi nilai per lembar saham & & 185 \\
\hline
\end{tabular}

\section{Rekonsiliasi Nilai}

Hasil penilaian dengan menggunakan kedua pendekatan tersebut menghasilkan indikasi nilai yang berbeda. Penilaian pada Tabel 9 menunjukkan bahwa menggunakan metoda discounted cash flow dengan free cash flow to equity memberikan indikasi nilai per lembar saham PT PP Properti sebesar Rp176,00 sementara penilaian yang dilakukan dengan metoda relative valuation menghasilkan indikasi nilai yaitu sebesar Rp185,00. 
Tabel 9. Hasil Rekonsiliasi Nilai PT PP Properti

\begin{tabular}{|c|c|c|c|}
\hline Metode/ Model & Indikasi Nilai & Bobot & Nilai Tertimbang \\
\hline \multicolumn{4}{|l|}{ Discounted Cash Flow Method } \\
\hline Free Cash Flow to Equity Model & 176 & & \\
\hline Jumlah (A) & 176 & $50 \%$ & 88 \\
\hline \multicolumn{4}{|l|}{ Relative Valuation } \\
\hline Price Earnings Ratio (PER) & 305 & & \\
\hline Price to Book Value (PBV) & 226 & & \\
\hline Price to Sales Ratio (P/S) & 26 & & \\
\hline Rata-rata (B) & 185 & $50 \%$ & 93 \\
\hline Jumlah $(\mathrm{A}+\mathrm{B})$ & & $100 \%$ & 181 \\
\hline Estimasi Nilai Wajar Per Lembar Saham & & & 181 \\
\hline Range Nilai Penetapan Saham & 167 & & 194 \\
\hline
\end{tabular}

\section{PEMBAHASAN}

Dalam penelitian ini, hasil penawaran saham yang ditetapkan pihak manajemen PT PP Properti pada saat IPO sebesar Rp100,00, sementara estimasi nilai wajar per lembar saham sebesar Rp181,00. Dengan demikian harga saham yang ditetapkan PT PP Properti dalam rangka IPO adalah undervalued. Hal ini bisa saja terjadi dikarenakan adanya kepentingan dari underwriter terhadap penetapan harga jual. Disamping itu, harga saham dalam IPO yang undervalued berarti mencerminkan adanya DLOM yang cukup besar yaitu sebesar $44 \%$ dari perhitungan (181-100) dibagi dengan 181.

Menurut penelitian yang dilakukan oleh Kristiantari (2013), fenomena underpricing terjadi di pasar modal berbagai negara, diantaranya adalah Amerika Serikat, Inggris, Australia, Afrika Selatan, China, Malaysia, dan Indonesia. Hasil penelitian menunjukkan reputasi underwriter, ukuran perusahaan, dan tujuan penggunaan dana untuk investasi berpengaruh pada underpricing, sedangkan variabel reputasi auditor, umur perusahaan, profitabilitas perusahaan (ROA), financial leverage, dan jenis industri terbukti tidak memiliki pengaruh signifikan pada terjadinya underpricing.

\section{SIMPULAN DAN SARAN}

\section{Simpulan}

Berdasarkan analisis yang telah dilakukan pada bab sebelumnya, maka hasil yang dapat disimpulkan dari penelitian ini adalah terjadinya kondisi yang undervalued terhadap harga penawaran yang ditetapkan pada saat IPO oleh PT PP Properti. Selisih dari harga saham penawaran dalam IPO dan harga saham dalam penilitian ini bisa menjadikan bahan pertimbangan dalam penentuan DLOM. Sebagaimana diketahui bahwa dalam peraturan Keputusan Ketua BAPEPAM \& LK d/ h. OJK No. 340 Tahun 2009, bahwa dalam dalam penilaian usaha yang dilakukan wajib mempertimbangkan adanya DLOM, sehingga penelitian terhadap besaran DLOM sangat penting dilakukan.

\section{Saran}

Pada penelitian ini hanya menggunakan pendekatan pendapatan dengan metode FCFE dan relative valuation dengan multiple $\mathrm{PER}, \mathrm{PBV}$, dan $\mathrm{P} /$ $S$, sehingga untuk penelitian selanjutnya disarankan menggunakan pendekatan pendapatan dengan metode FCFF dan multiple dari metode relative valu- 


\section{Jurnal Keuangan dan Perbankan | KEUANGAN}

Vol. 21, No.1, Januari 2017: 37- 46

ation lainnya dengan tujuan dapat melengkapi penelitian ini atau sebagai komparasi perbandingan terhadap hasil penelitian ini. Disamping itu, objek penelitian ke depannya bisa diperluas terhadap perusahaan lainnya yang melakukan penawaran harga perdana saham kepada publik.

\section{DAFTAR PUSTAKA}

Abid, M.T. \& Muharam, H. 2013. Analisis Faktor-Faktor yang Mempengaruhi Abnormal Return Saham pada Kinerja Jangka Panjang Penawaran Umum Perdana (IPO). Jurnal Studi Manajemen E Organisasi, 10(2).

Brigham, E.F. \& Ehrhardt, M.C. 2009. Financial Management Theory and Practice: Twelfth Edition. South Western: Thomson.

Damodaran A., 2012. Investment Valuation: Tools and Techniques for Determining the Value of Any Asset (University Edition). New Jersey: John Wiley \& Sons.

Emilia, E., Sulaiman, L., \& Sembel, R. 2008. Faktor-Faktor yang Mempengaruhi Initial Return 1 Hari, Return 1 Bulan, dan Pengaruh terhadap Return 1 Tahun Setelah IPO. Journal of Applied Finance and Accounting, 1(1): 116-140.

Haryanto, H. \& Kartawinata, B.R. 2014. Analisis Kinerja Saham pada Perusahaan yang Melakukan Initial Public Offering (IPO) di Bursa Efek Indonesia. Jurnal Eproc.

Kristiantari, I.D.A. 2013. Analisis Faktor-Faktor yang Mempengaruhi Underpricing Saham pada Penawaran Saham Perdana di Busa Efek Indonesia. Jurnal Ilmiah Akuntansi dan Humanika, 2(2).

Aisyah, I.S. 2009. Pengaruh Variabel-Variabel Keuangan pada Initial Return Saham di Pasar Perdana. Jurnal Trikonomika, 8(1): 22-31.

Keputusan Kepala Badan Pengawas Pasar Modal dan Lembaga Keuangan. Pedoman Penilaian dan Penyajian Laporan Penilaian Usaha di Pasar Modal, KEP- 196/BL/ 2012.
Mahendra, A., Artini, L.G.S, \& Suarjaya, A.A.G. 2012. Pengaruh Kinerja Keuangan terhadap Nilai Perusahaan pada Perusahaan Manufaktur di Bursa Efek Indonesia. Jurnal Manajemen, Strategi Bisnis, dan Kewirausahaan, 6(2).

Muttaqim, H. 2013. Analisis Valuasi Saham PT. Adhi Karya (Persero) Tbk. dengan Metode Discounted Cash Flow (DCF). Journal of Economic Management $\mathcal{E}$ Business, 14(4): 391-396.

Noor, M.S. \& Satyawan, M.D. 2014. Analisis Penilaian Harga Wajar Saham Studi Kasus pada PT Multi Bintang Indonesia, Tbk. Jurnal Ilmu Manajemen, 2(3).

Singgih, M. 2012. Penilaian Kewajaran Harga Saham Sebagai Pertimbangan Investasi di Bursa Efek Indonesia. Jurnal Bisnis dan Manajemen, 6(1): 38-69.

Solechan, A. 2009. Pengaruh Earning, Manajemen Laba, IOS, Beta, Size, dan Rasio Hutang terhadap Return Saham pada Perusahaan yang Go Public di BEI. Jurnal Akuntansi dan Auditing, 6(1).

Sunardi, H. 2010. Pengaruh Penilaian Kinerja dengan ROI dan EVA terhadap Return Saham pada Perusahaan yang Tergabung dalam Indeks LQ 45 di Bursa Efek Indonesia. Jurnal Akuntansi, 2(1): 7092.

Umanto, E. 2008. Analisis dan Penilaian Kinerja Portofolio Optimal Saham-Saham LQ 45. Jurnal Ilmu Administrasi dan Organisasi, 15(3): 178-187.

Younesi, N., Ardekani, A.M., \& Hashemijoo, M. 2012. Performance of Malaysian IPOs and Impact of Return Determinants. Journal of Business Studies Quarterly, 4(2): 140-158.

Wardani, S. \& Fitriati, R. 2010. Analisis Komparasi Profitabilitas Sebelum dan Sesudah Penawaran Umum Saham Perdana. Jurnal Ilmu Administrasi dan Organisasi, 17(2): 90-100. 